\title{
Antinociceptive effect of novel pyrazolines in mice
}

Z. Tabarelli ${ }^{1}$ M.A. Rubin², D.B. Berlese' ${ }^{2}$, P.D. Sauzem², T.P. Missio², M.V. Teixeira ${ }^{3}$, A.P. Sinhorin ${ }^{3}$, M.A.P. Martins ${ }^{3}$, N. Zanatta ${ }^{3}$, H.G. Bonacorso ${ }^{3}$ and C.F. Mello ${ }^{1,2}$

\author{
${ }^{1}$ Departamento de Fisiologia, Centro de Ciências da Saúde, \\ ${ }^{2}$ Laboratório de Neurotoxicidade e Psicofarmacologia, and \\ ${ }^{3}$ Núcleo de Química de Heterociclos (NUQUIMHE), \\ Departamento de Química, Centro de Ciências Naturais e Exatas, \\ Universidade Federal de Santa Maria, Santa Maria, RS, Brasil
}

\author{
Correspondence \\ M.A. Rubin \\ Departamento de Química \\ Centro de Ciências Naturais e Exatas \\ Universidade Federal de Santa Maria \\ 97105-900 Santa Maria, RS \\ Brasil \\ Fax: +55-55-220-8031. \\ E-mail: marubin@smail.ufsm.br \\ Research supported by CNPq/ \\ PADCTIII (No. 62.0228/97-0-QEQ) \\ and FAPERGS (No. 01/1338.9). \\ M.A. Rubin, M.A.P. Martins, \\ N. Zanatta, H.G. Bonacorso, and \\ C.F. Mello are recipients of CNPq \\ fellowships (Nos. 500096/2003-1, \\ 303116/2002-0, 301474/2003-6, \\ 303636/2002-5, and 500120/2003-0, \\ respectively).
}

Received November 18, 2003 Accepted June 22, 2004

\begin{abstract}
The antinociceptive effect of six novel synthetic pyrazolines (3ethoxymethyl-5-ethoxycarbonyl-1H-pyrazole (Pz 1) and its corresponding 1-substituted methyl (Pz 2) and phenyl (Pz 3) analogues, and 3-(1-ethoxyethyl)-5-ethoxycarbonyl-1H-pyrazole (Pz 4) and its corresponding 1-substituted methyl ( $\mathrm{Pz} 5$ ) and phenyl ( $\mathrm{Pz} 6$ ) analogues) was evaluated by the tail immersion test in adult male albino mice. The animals ( $\mathrm{N}=11-12$ in each group) received vehicle (5\% Tween 80, 10 $\mathrm{ml} / \mathrm{kg}, s c$ ) or $1.5 \mathrm{mmol} / \mathrm{kg}$ of each of the pyrazolines (Pz 1-Pz 6), sc. Fifteen, thirty and sixty minutes after drug administration, the mice were subjected to the tail immersion test. Thirty minutes after drug administration $\mathrm{Pz} 2$ and $\mathrm{Pz} 3$ increased tail withdrawal latency (vehicle $=3.4 \pm 0.2 ; \mathrm{Pz} 2=5.2 \pm 0.4 ; \mathrm{Pz} 3=5.9 \pm 0.4 \mathrm{~s} ;$ mean $\pm \mathrm{SEM}$ ), whereas the other pyrazolines did not present antinociceptive activity. Doseeffect curves ( 0.15 to $1.5 \mathrm{mmol} / \mathrm{kg}$ ) were constructed for the bioactive pyrazolines. $\mathrm{Pz} 2(1.5 \mathrm{mmol} / \mathrm{kg}, s c)$ impaired motor coordination in the rotarod and increased immobility in the open-field test. Pz 3 did not alter rotarod performance and spontaneous locomotion, but increased immobility in the open field at the dose of $1.5 \mathrm{mmol} / \mathrm{kg}$. The involvement of opioid mechanisms in the pyrazoline-induced antinociception was investigated by pretreating the animals with naloxone ( $2.75 \mu \mathrm{mol} / \mathrm{kg}, s c)$. Naloxone prevented Pz 3- but not Pz 2-induced antinociception. Moreover, naloxone pretreatment did not alter Pz 3induced immobility. We conclude that Pz 3-induced antinociception involves opioid mechanisms but this is not the case for $\mathrm{Pz} 2$.
\end{abstract}

Key words

- Pyrazole-derived

compounds

- Antinociception

- Tail immersion test

- Rotarod test

- Open-field test

- Immobility

\section{Introduction}

Some pyrazole-derived compounds such as pyrazolidinediones possess a number of pharmacological and biochemical properties, which include oxidative phosphorylation uncoupling, stabilization of lysosomal membranes, inhibition of the biosynthesis of various mucopolysaccharides, and, perhaps most importantly, inhibition of prostaglandin biosynthesis in the cyclooxygenase step (1).

Due to their ability to inhibit cyclooxy- 
genase activity and the arachidonic acid cascade, pyrazole-derived compounds, including dipyrone, have anti-inflammatory, antipyretic and analgesic properties (2-6). Because of these properties, these drugs have been classified as nonsteroidal anti-inflammatory drugs (NSAIDs), and their administration results in a reduced synthesis of peripherally and centrally formed prostaglandins (2,4,7-9), which physiologically enhance the sensitivity of the primary afferent to algogenic substances (10). However, other mechanisms of action have been proposed for the antinociception induced by pyrazolederived compounds, such as decrease of on/ off cell firing in the periaqueductal gray (11) and activation of opioid mechanisms (12). It is worth noting, however, that the pharmacological profile of pyrazole-derived compounds is not homogeneous, since lack of anti-inflammatory activity has also been described for different pyrazole-derived compounds, as well as independence of opioid mechanisms (13).

In the present study, we describe the antinociceptive action of a new series of pyrazole-derived compounds and the involvement of opioid mechanisms in this effect. The effects of bioactive pyrazolines on other behavioral measures, such as spontaneous and forced locomotion (rotarod testing) were also evaluated.

\section{Material and Methods}

The present study was conducted in accordance with the ethical guidelines established for investigations of experimental pain in conscious animals (14) and was approved by the Ethics Committee for the Use of Animals in Research of Universidade Federal de Santa Maria, RS, Brazil.

\section{Animals}

Male albino mice weighing 25-35 $\mathrm{g}$ were used. The animals had free access to water and food and were maintained on a 12-h light/dark cycle under conditions of controlled temperature $\left(23 \pm 1^{\circ} \mathrm{C}\right)$ and humidity (40-60\%).

\section{Drugs}

3-Ethoxymethyl-5-ethoxycarbonyl- $1 H$ pyrazole $(\mathrm{Pz} 1)$, and its corresponding 1substituted methyl (Pz 2) and phenyl (Pz 3) analogues were obtained from the cyclocondensation reaction of 5-bromo-1,1,1trichloro-4-methoxy-3-penten-2-one $(15,16)$ with hydrazine (methyl hydrazine or phenyl hydrazine) using ethanol as a solvent. 3-(1Ethoxyethyl)-5-ethoxycarbonyl-1H-pyrazole ( $\mathrm{Pz} 4)$ and its corresponding 1-substituted methyl (Pz 5) and phenyl (Pz 6) analogues were obtained from the cyclo-condensation reaction of 5-bromo-1,1,1-trichloro-4-methoxy-3-hexen-2-one $(15,16)$ with methyl hydrazine or phenyl hydrazine using ethanol as a solvent. These cyclo-condensation reaction proceeds with simultaneous transformation of the trichloromethyl group into an ethoxycarbonyl group and of the bromomethyl group into an etoxymethyl group, according to methodologies developed in our laboratory (16). Tween 80 and naloxone were purchased from Sigma (St. Louis, MO, USA).

Pyrazolines were suspended in 5\% Tween $80(0.5,1.0$ or $1.5 \mathrm{mmol} / 10 \mathrm{ml})$; naloxone $(2.75 \mu \mathrm{mol} / 10 \mathrm{ml})$ and morphine sulfate $(6.6$ $\mu \mathrm{mol} / 10 \mathrm{ml})$ were dissolved in saline. All solutions were administered subcutaneously (sc, $10 \mathrm{ml} / \mathrm{kg}$ ).

\section{Tail immersion test}

The tail immersion test was carried out to determine whether one or more of the novel pyrazolines caused antinociception. Twentyfour hours before the experiment, all mice were habituated to the experimental procedure (subcutaneous injection and measurement of tail withdrawal latency) in order to minimize novelty-induced antinociception 
(17). On the day of the experiment the animals were injected $s c$ with vehicle (5\% Tween 80) or Pz 1, Pz 2, Pz 3, Pz 4, Pz 5, or Pz 6 at the dose of $1.5 \mathrm{mmol} / \mathrm{kg}$, and subjected to the tail immersion test 15, 30 and $60 \mathrm{~min}$ thereafter. Drug doses were selected according to the maximal concentration achievable in a homogeneous suspension on an equimolar basis (maximal possible dose).

The tail immersion test was carried out as described by Janssen et al. (18). The tailflick latency of each animal was determined by immersing the lower $3.5 \mathrm{~cm}$ of the tail into a cup filled with water from a large constant temperature $\left(55^{\circ} \mathrm{C}\right)$ bath and recording the tail withdrawal latency (in seconds) with a manual stopwatch. A cut-off time of $7 \mathrm{~s}$ was established in order to prevent tissue damage.

When the compounds which caused antinociception were identified, a dose-response curve was constructed for each one. $\mathrm{Pz} 2$ and $\mathrm{Pz} 3(0.15-1.5 \mathrm{mmol} / \mathrm{kg})$ were administered 30 min before the tail immersion test, since the first set of experiments showed that after 60 min their antinociceptive effect had completely vanished. Five minutes after the tail immersion test the animals were subjected to the rotarod test.

In the experiments designed to evaluate the participation of opioid mechanisms in $\mathrm{Pz}$ 2- and $\mathrm{Pz}$ 3-induced antinociception, animals were injected with naloxone $(2.75 \mu \mathrm{mol} /$ $\mathrm{kg}, s c)$ or saline $(0.9 \% \mathrm{NaCl}, 10 \mathrm{ml} / \mathrm{kg}, s c) 20$ min before the injection of vehicle $(5 \%$ Tween $80,10 \mathrm{ml} / \mathrm{kg}$ ) or of the pyrazolines ( $\mathrm{Pz} 2$ or $\mathrm{Pz} 3$ at $1.5 \mathrm{mmol} / \mathrm{kg}$ ), and subjected to the same experimental protocol as described above.

\section{Rotarod evaluation}

The rotarod test was used to assess whether $\mathrm{Pz} 2$ and $\mathrm{Pz} 3$ caused gross motor impairment in the animals. Twenty-four hours before the experiment, all mice were habituated to running in a rotarod $(3.7 \mathrm{~cm}$ in diam- eter, $8 \mathrm{rpm}$ ) until they could remain there for $60 \mathrm{~s}$ without falling. Five minutes after the measurement of tail withdrawal (35 min after $s c$ injection of vehicle or pyrazolines), each mouse was tested in the rotarod. The latency to fall, as well as the number of falls from the apparatus, were recorded with a stopwatch up to $240 \mathrm{~s}$ (19-21).

\section{Open-field evaluation}

The effect of the compounds on spontaneous locomotor activity and exploratory behavior was assessed by the open-field test, as previously reported (19). The apparatus was a round arena (34 $\mathrm{cm}$ in diameter) with the floor divided into 21 equal areas. Immediately after rotarod evaluation (40 min after $s c$ injection of vehicle or pyrazolines), the animals were transferred to the apparatus and observed for $5 \mathrm{~min}$. The number of rearing responses, number of areas crossed with all paws, and total time spent immobilized (immobility) were recorded.

\section{Statistical analysis}

The tail withdrawal latencies, the latency to the first fall from the rotarod, the number of falls from the rotarod, and the duration of immobility were analyzed by one-way ANOVA. Data were square root transformed before analysis in order to meet the assumptions for ANOVA. Post hoc tests (StudentNewman-Keuls test) were carried out when appropriate.

In those experiments designed to evaluate the dose-response relationships, the ANOVA between groups sum of squares test was partitioned into trend components (linear, quadratic or cubic). Data from experiments designed to evaluate the participation of opioid mechanisms in pyrazolineinduced analgesia were analyzed by twoway ANOVA. The level of significance was set at $\mathrm{P}<0.05$ and $\mathrm{F}$ values are presented in the text only when $\mathrm{P}<0.05$. All behavioral 
Table 1. Effects of pyrazoles 1, 2 and 3 and morphine on mouse tail withdrawal latency (in seconds) at 15, 30 and 60 min after injection.

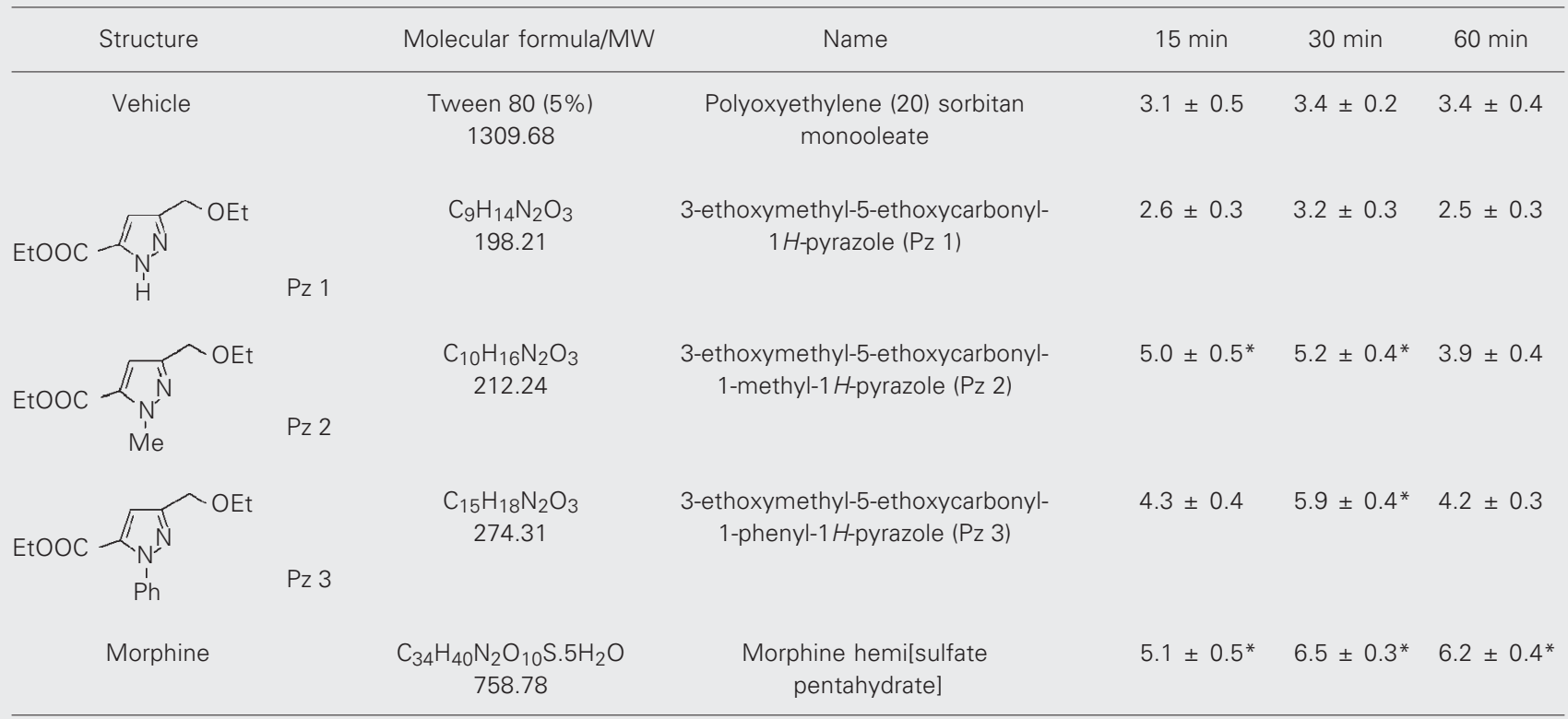

The structures of Pz 1 to 3 are given in the first column. The pyrazoles $(1.5 \mathrm{mmol} / \mathrm{kg})$ and morphine $(6.6 \mu \mathrm{mol} / \mathrm{kg})$ were injected subcutaneously. Data are reported as mean \pm SEM for $\mathrm{N}=11-12$ animals per group.

${ }^{*} \mathrm{P}<0.001$ compared with vehicle (5\% Tween 80 ) group (Student-Newman-Keuls test).

Table 2. Effects of pyrazoles 4, 5 and 6 and morphine on mouse tail withdrawal latency (in seconds) at 15, 30 and 60 min after injection.

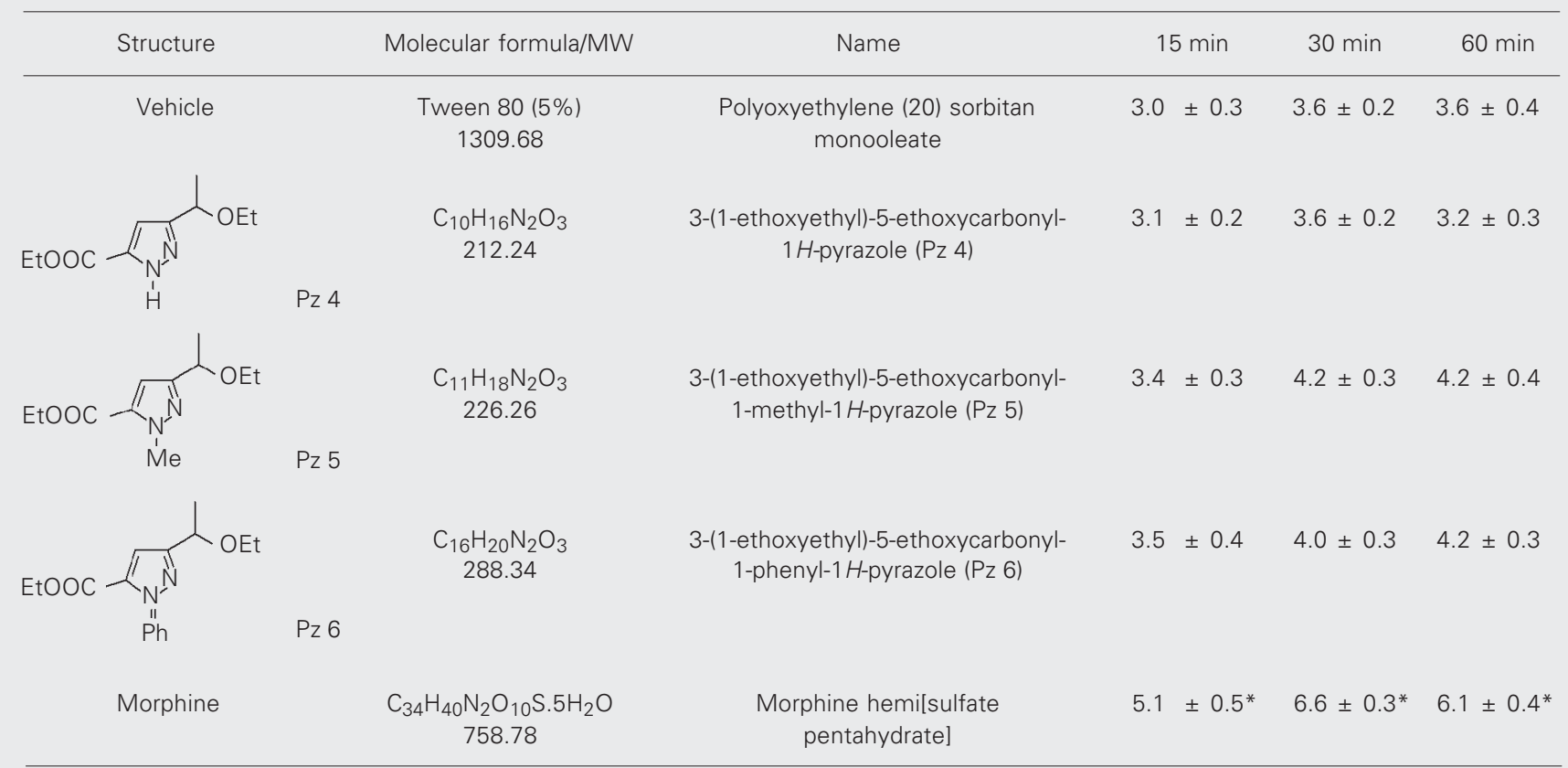

The structures of Pz 4 to 6 are given in the first column. The pyrazoles $(1.5 \mathrm{mmol} / \mathrm{kg})$ and morphine $(6.6 \mu \mathrm{mol} / \mathrm{kg})$ were injected subcutaneously. Data are reported as mean \pm SEM for $\mathrm{N}=11-12$ animals per group.

${ }^{*} \mathrm{P}<0.001$ compared with vehicle (5\% Tween 80 ) group (Student-Newman-Keuls test). 
data were scored by two observers who were not aware of the animals' treatment, with $>90 \%$ agreement between them.

\section{Results}

\section{Tail immersion test}

Table 1 shows the effect of $\mathrm{Pz} 1$ and its corresponding 1-substituted methyl $(\mathrm{Pz} 2)$ and phenyl (Pz 3$)$ analogues $(1.5 \mathrm{mmol} / \mathrm{kg})$ on the latency of tail withdrawal from hot water. Morphine $(6.6 \mu \mathrm{mol} / \mathrm{kg})$ was included in the experiment as an internal standard. Statistical analysis (one-way ANOVA) of tail withdrawal latencies revealed a significant effect of treatment at $15[\mathrm{~F}(4,53)=6.39$, $\mathrm{P}<0.001], 30[\mathrm{~F}(4,53)=16.16, \mathrm{P}<0.001]$ and $60[\mathrm{~F}(4,53)=19.68, \mathrm{P}<0.001] \mathrm{min}$. Post hoc analysis (Student-Newman-Keuls test) revealed that $\mathrm{Pz} 2$ and morphine increased tail withdrawal latencies 15 min after their administration, while $\mathrm{Pz} 2, \mathrm{Pz} 3$ and morphine increased withdrawal latencies 30 min after their administration. However, only morphine induced significant antinociception $1 \mathrm{~h}$ after its administration. Pz 1 did not alter tail withdrawal latencies at any time tested.

Table 2 shows the effect of $\mathrm{Pz} 4$ and its corresponding 1-substituted methyl $(\mathrm{Pz} 5)$ and phenyl (Pz 6) analogues $(1.5 \mathrm{mmol} / \mathrm{kg})$ on the latency of tail withdrawal from hot water. Statistical analysis (one-way ANOVA) revealed that $\mathrm{Pz} 4, \mathrm{Pz} 5$ and $\mathrm{Pz} 6$ did not alter tail withdrawal latencies, while morphine increased withdrawal latencies at all times tested, $15[\mathrm{~F}(4,49)=5.12, \mathrm{P}<0.002], 30$ $[\mathrm{F}(4,49)=19.87, \mathrm{P}<0.001]$ and $60[\mathrm{~F}(4,49)$ $=8.79, \mathrm{P}<0.001] \mathrm{min}$ (post hoc analysis by the Student-Newman-Keuls test).

Once the pyrazolines that presented antinociceptive activity were identified, a doseresponse curve was constructed for each bioactive compound. Figure $1 \mathrm{~A}$ shows the effects of increasing amounts of $\mathrm{Pz} 2$ on the latency of tail withdrawal from a hot water bath. Statistical analysis (one-way ANOVA followed by the Student-Newman-Keuls test) revealed that $\mathrm{Pz} 2(1.5 \mathrm{mmol} / \mathrm{kg})$ administration significantly increased tail withdrawal latency $[\mathrm{F}(3,28)=12.40, \mathrm{P}<0.001]$. Partitioning of the total sum of squares into trend components revealed that $\mathrm{Pz} 2$ increased withdrawal latencies linearly in a dose-dependent manner $[\mathrm{F}(1,28)=34.00, \mathrm{P}<0.001]$.

Figure 1B shows the effect of increasing

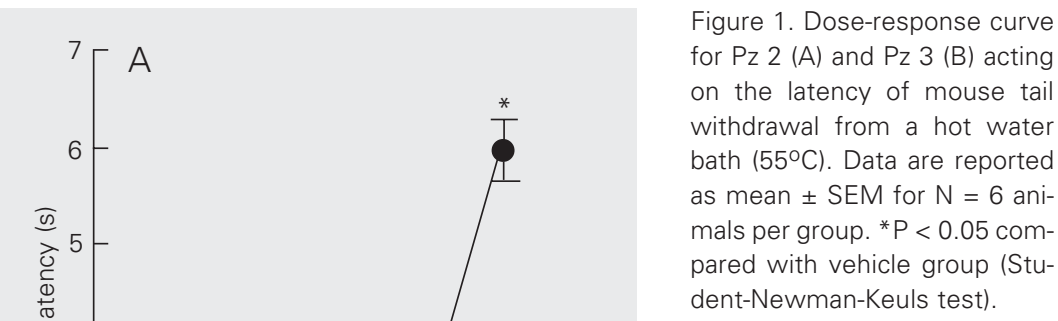
dent-Newman-Keuls test). 
Pz 3 doses on the latency of tail withdrawal from a hot water bath. Statistical analysis revealed that $\mathrm{Pz} 3$ linearly increased tail withdrawal latencies $[\mathrm{F}(3,26)=6.30, \mathrm{P}<$ 0.002 ] in a dose-dependent manner [significant linear trend: $\mathrm{F}(1,26)=8.94, \mathrm{P}<0.01]$.

\section{Rotarod evaluation}

Figure 2A,B shows the effect of $\mathrm{Pz} 2$ on the rotarod performance of mice. Statistical
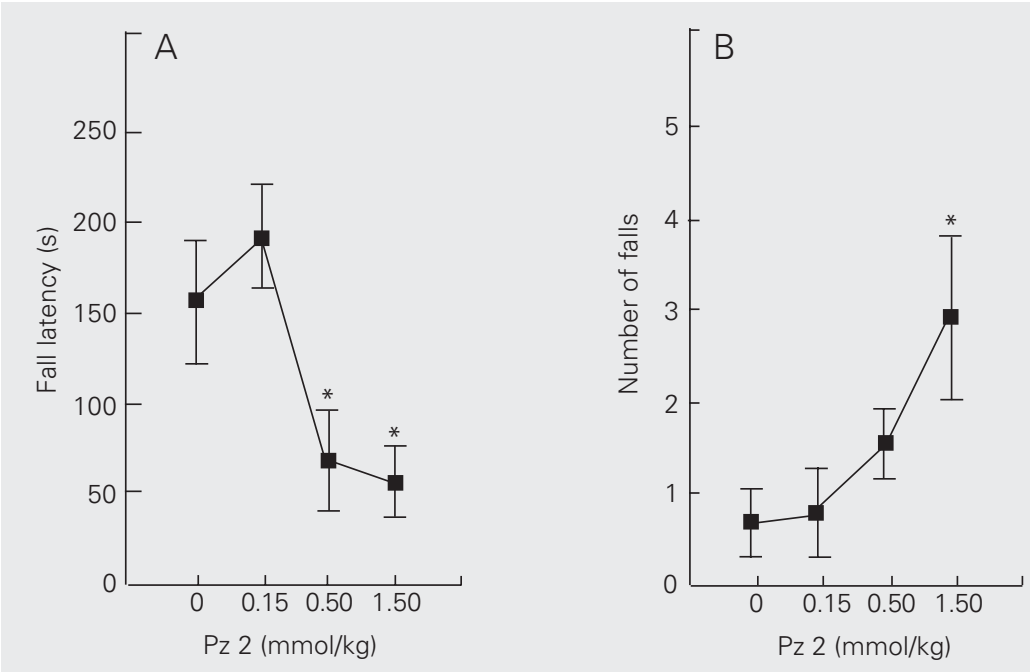

Figure 2. Effects of $P z 2$ administration on the latency for the first fall $(A)$ and on the number of falls (B) from the rotarod. Data are reported as means \pm SEM for $N=8$ animals per group. ${ }^{*} \mathrm{P}<0.05$ compared with vehicle group (Student-Newman-Keuls test).
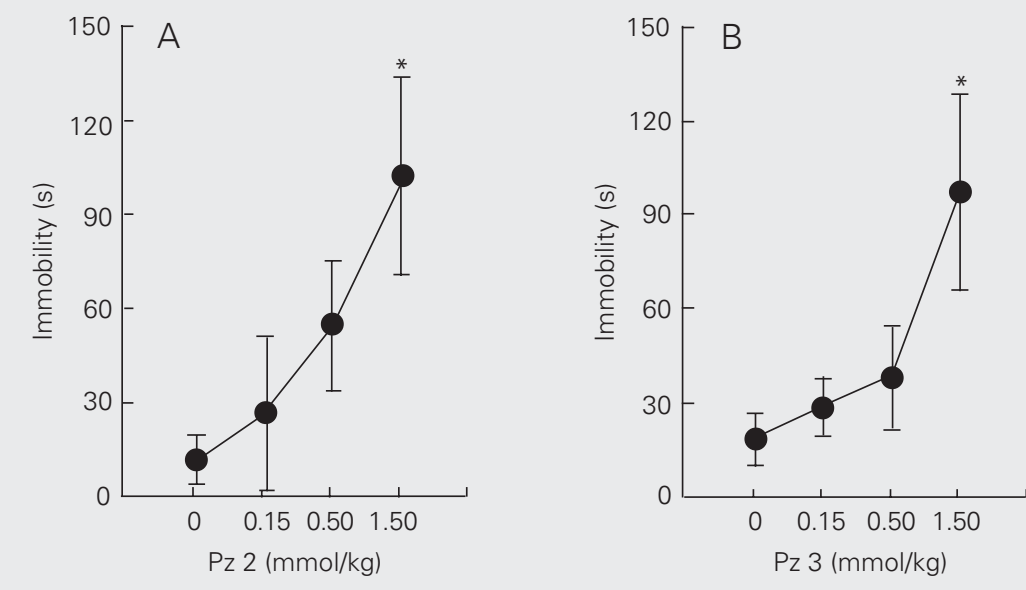

Figure 3. Effects of Pz 2 (A) and Pz 3 (B) on time spent immobilized (immobility) in the open field. Data are reported as means \pm SEM for $N=8$ animals per group. ${ }^{*} \mathrm{P}<0.05$ compared with vehicle group (Student-Newman-Keuls test). analysis (one-way ANOVA followed by the Student-Newman-Keuls test) showed that $\mathrm{Pz}$ $2(0.5$ and $1.5 \mathrm{mmol} / \mathrm{kg})$ decreased the latency for the first fall from the rotarod $[\mathrm{F}(3,28)=5.80, \mathrm{P}<0.05]$ and that $\mathrm{Pz} 2(1.5$ $\mathrm{mmol} / \mathrm{kg}$ ) increased the number of falls from the rotarod $[F(3,28)=3.22, P<0.03]$ in a 4 min session, suggesting that $\mathrm{Pz} 2$ causes some degree of motor impairment.

In contrast to $\mathrm{Pz} 2, \mathrm{Pz} 3$ did not alter rotarod performance (data not shown).

\section{Open-field evaluation}

$\mathrm{Pz} 2$ and $\mathrm{Pz} 3$ did not alter the number of crossings or the number of rearing responses in the open-field test (data not shown), but increased immobility in the open field $[\mathrm{F}(3,28)=3.80, \mathrm{P}<0.03$ and $\mathrm{F}(3,26)=3.55$, $\mathrm{P}<0.03$ - for $\mathrm{Pz} 2$ (Figure $3 \mathrm{~A}$ ) and $\mathrm{Pz} 3$ (Figure 3B), respectively]. Taken together, these data suggest that some degree of motor impairment occurs in the presence of $\mathrm{Pz} 2$ and $\mathrm{Pz}$ 3. Due to the deleterious effect of $\mathrm{Pz}$ 2 in the rotarod and in the open-field test, it is not possible to definitely rule out a motor effect in the antinociceptive effect of $\mathrm{Pz} 2$ reported here. $\mathrm{Pz} 3$ also seems to cause some degree of motor impairment, but only if immobility in the open field is considered.

\section{Involvement of opioid mechanisms}

The involvement of opioid mechanisms in $\mathrm{Pz} 2$ - and $\mathrm{Pz}$ 3-induced antinociception was investigated by pre-administering naloxone, a nonselective opioid antagonist. Figure 4A shows that naloxone pre-administration prevented $\mathrm{Pz} 3$-, but not $\mathrm{Pz}$ 2-induced antinociception (significant pretreatment (saline or naloxone) $\mathrm{x}$ treatment (Tween, $\mathrm{Pz} 2$ or $\mathrm{Pz}$ 3) interaction $-[\mathrm{F}(2,66)=3.90, \mathrm{P}<0.05]$, suggesting the involvement of opioid mechanisms in the presently reported antinociceptive effect of $\mathrm{Pz} 3$. Naloxone, on the other hand, did not alter Pz 3-induced immobility in the open field (Figure 4B). 


\section{Discussion}

The present study reports the antinociceptive effect of two novel pyrazole-derived compounds ( $\mathrm{Pz} 2$ and $\mathrm{Pz} 3$ ) and the involvement of opioid mechanisms in $\mathrm{Pz}$ 3-induced antinociception. Some preliminary conclusions about the structure-activity relationship can be drawn from the comparison of the antinociceptive activity between pyrazole derivatives. It is clear from the structures given in Tables 1 and 2 that the presence of a methyl or a phenyl substituent group at the 1-position of the pyrazole ring increases antinociceptive activity, while the ramification of the lateral chain at the 3-position of the pyrazole ring decreases it. Apart from possible pharmacokinetic differences that could account for the differential antinociceptive effect of these compounds, it is remarkable that a similar structure-activity relationship has been described for the anti-inflammatory activity of pyrazole derivatives, since the presence of a phenyl group at the 1position of the ring also increases the antiinflammatory activity of 3,5-pyrazolinediones (1).

Anti-inflammatory agents (including 3,5pyrazolinediones) are usually devoid of antinociceptive activity in thermal stimulation tests (22). Therefore, although it seems unlikely that a putative anti-inflammatory action underlies the presently reported antinociceptive action of $\mathrm{Pz} 2$ and $\mathrm{Pz} 3$, further specific studies about the anti-inflammatory potential of these compounds are necessary to clarify this point. Opioid agonists are known to cause antinociception in thermal stimulation tests (23-26), a fact that suggests an opioid-like action for the tested pyrazole derivatives. As will be discussed below, the present suggestion of the involvement of opioid mechanisms in $\mathrm{Pz}$ 3-induced antinociception was corroborated by the finding that naloxone prevented $\mathrm{Pz} 3$-induced antinociception.

A major concern in experiments designed to evaluate the analgesic action of new agents is whether pharmacological treatment causes other behavioral alterations, such as motor incoordination and sedation, which might be misinterpreted as analgesia. In the present study, we demonstrate that $\mathrm{Pz} 2$ causes motor incoordination in the rotarod test (as judged by the decreased latency to fall from the apparatus and increased number of falls in a 4-min session). Accordingly, $\mathrm{Pz} 2$ increased immobility in the open-field test, suggesting that this compound causes some degree of motor impairment (or sedation), which might underlie its antinociceptive effect. Therefore, our data do not permit us to conclude that $\mathrm{Pz} 2$ is an analgesic.

However, Pz 3, the other pyrazoline that had antinociceptive activity (see Table 1 and Figure 1B), had no effect on rotarod performance (data not shown), suggesting that this compound does not cause gross motor impairment. Nevertheless, despite the lack of effect on the rotarod test, $\mathrm{Pz} 3$, at doses that caused antinociception in the tail immersion test, increased immobility in the open field (Figure 3B).

It has been suggested that an altered exploratory behavior in the open field may be

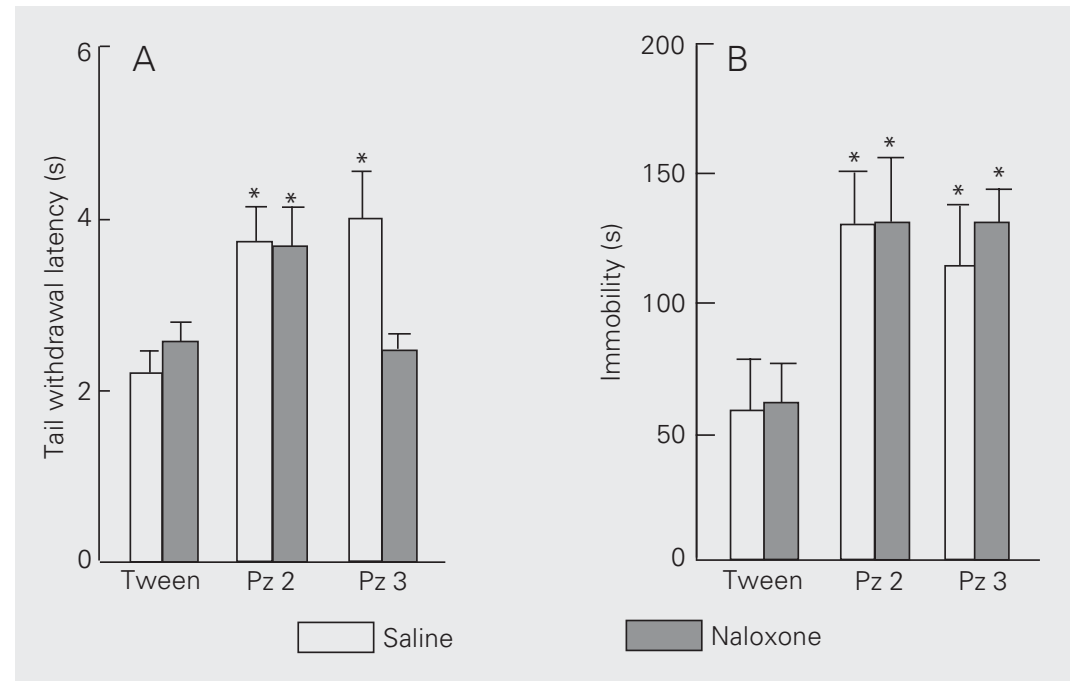

Figure 4. Effect of naloxone on the antinociception (A) and immobility (B) induced by Pz 2 and Pz 3. Naloxone $(2.75 \mu \mathrm{mol} / \mathrm{kg})$ and $\mathrm{Pz} 2$ and $3(1.5 \mathrm{mmol} / \mathrm{kg})$ were injected sc. Data are reported as means \pm SEM for $N=7-9$ animals per group. ${ }^{*} \mathrm{P}<0.05$ compared with vehicle (Tween) group (Student-Newman-Keuls test). 
caused by alterations in the anxiety state and/or sedation (27). Since it is not known whether Pz 3 modifies the animals' anxiety state, it is not possible to rule out the involvement of these factors in the antinociceptive effect of this compound. On the other hand, $\mathrm{Pz} 3$-induced antinociception was prevented by the injection of naloxone at a dose that had no effect per se (Figure 4A).

Naloxone, a nonselective opioid antagonist, has been widely used to demonstrate the involvement of opioid mechanisms of selected compounds in various behavioral tasks, including exploratory behavior and antinociceptive tests $(13,28-32)$. The prevention of $\mathrm{Pz} 3$-induced antinociception by naloxone supports the involvement of opioid mechanisms in this effect. Moreover, although the reversal of the $\mathrm{Pz} 3$ antinociceptive activity by naloxone does not guarantee an analgesic role for this compound, it is rather possible, due to the fairly known selective role of opioid mechanisms in analgesia, that the antinociceptive effects of $\mathrm{Pz} 3$ are, in fact, related to opioid analgesia. Moreover, it is worth mentioning that the reversal of $\mathrm{Pz} 3$ effects by naloxone was restricted to the antinociceptive action of this compound (Figure 4B), suggesting that the antinociceptive effects of $\mathrm{Pz} 3$ are not related to the concomitant increase in immobility (that was not altered by naloxone pretreatment).

This dissociation of the effects of naloxone on motor behavior and on antinociception is an effect of this opioid antagonist that has not been sufficiently addressed. A great deal of the difficulties in elucidating the effect of naloxone and of opioid agonists on locomotor behavior is certainly due to the significant controversy that has appeared in the literature regarding the contribution of each opioid receptor subtype to the locomotor stimulation induced by opioids in mice. A large number of studies have proposed that the opioid-induced increase of locomotor activity in mice is related to $\mu$ and $\delta$, but not $\kappa$ receptor stimulation (33-35), since $\kappa$ agonists, in general, cause a decrease in locomotion, while $\mu$ and $\delta$ agonists increase it. The effects of these opioid agonists on locomotion have been attributed to a modulation of the dopaminergic mesolimbic and nigrostriatal pathways by opioid receptors (36-38). The inhibitory effect of $\kappa$ agonists on locomotion is reverted by the specific $\kappa$ antagonist nor-binaltorphimine (nor-BNI) (39). 'Nevertheless, stimulatory effects of $\kappa$ agonists at low doses have also been described (39). To further complicate the interpretation of these pharmacological data, it has been demonstrated that the increase of locomotor activity induced by low doses of $\kappa$ agonists is not reversed by nor-BNI, but is completely eliminated by naloxone (39). Therefore, these studies (and others, related to opioid analgesia) reveal a complex interaction between $\mu$ and $\kappa$ receptors (38), indicating that further investigation is needed to explain these conflicting data.

Nevertheless, it is fairly well known that while naloxone decreases, morphine increases motor activity (13,28-32). Moreover, naloxone (at doses capable of preventing morphine-induced analgesia) prevents the increase of locomotor behavior induced by morphine (13). In this respect, $\mathrm{Pz} 3$ seems to be similar to $\kappa$ agonists and different from $\mu$ agonists such as morphine, since instead of increasing, Pz 3 decreases locomotor activity. Therefore, a selective effect of $\mathrm{Pz} 3$ on $\mathrm{\kappa}$ receptors cannot be ruled out if we consider that a decrease in locomotor activity is often associated with $\kappa$ receptor activation (but see the above comments on the conflicting role of $\kappa$ receptor agonists on locomotion).

We have described an interesting interaction of the effects of naloxone and another pyrazoline derivative, 3-methyl-5-hydroxy5-trichlomethyl-1H-1-pyrazolcarboxyamide (MPCA) (13). In that study we showed that naloxone (at a dose that has no effect on locomotion or antinociception per se) does not alter MPCA-induced antinociception but causes, in the presence of MPCA, a para- 
doxical increase in the locomotor behavior

tor effects of naloxone is an incompletely

of mice. Therefore, the currently reported

understood, but complex event, which mer-

dissociation of the antinociceptive and mo-

its further investigation.

\section{References}

1. Borne RF (1995). Nonsteroidal anti-inflammatory drugs. In: Foye WO, Lemke TL \& Williams DA (Editors), Principles of Medicinal Chemistry. Williams \& Wilkins, Baltimore, MD, USA.

2. Vane JR (1971). Inhibition of prostaglandin synthesis as a mechanism of action for aspirin-like drugs. Nature New Biology, 231: 232235.

3. Ferreira SH (1972). Prostaglandins, aspirin-like drugs and analgesia. Nature, 240: 200-203.

4. Ferreira SH, Lorenzetti BB \& Correa FM (1978). Central and peripheral antialgesic action of aspirin-like drugs. European Journal of Pharmacology, 53: 39-48.

5. Ku EC, Lee W, Kothari HV \& Scholer DW (1986). Effect of diclophenac sodium on the arachidonic acid cascade. American Journal of Medicine, 80: 18-23.

6. Campos C, Gregorio R, García-Nieto R, Gago F, Ortiz P \& Alemany S (1999). Regulation of cyclooxygenase activity by metamizol. European Journal of Pharmacology, 378: 339-347.

7. Ferreira SH, Moncada S \& Vane JR (1973). Prostaglandins and the mechanism of analgesia produced by aspirin-like drugs. British Journal of Pharmacology, 49: 86-97.

8. Flower RJ \& Vane JR (1972). Inhibition of prostaglandin synthetase in brain explains the antipyretic activity of acetaminophen. Nature, 240: 410-411.

9. Vane JR (1987). The evolution of non-steroidal anti-inflammatory drugs and their mechanisms of action. Drugs, 33: 18-27.

10. Millan MJ (1999). The induction of pain: an integrative review. Progress in Neurobiology, 57: 1-164.

11. Tortorici V \& Vanegas $H$ (1994). Putative role of medullary off- and on-cells in the antinociception produced by dipyrone (metamizol) administered systemically or microinjected into PAG. Pain, 57: 197205.

12. Tortorici $V$, Vasquez $E \&$ Vanegas $H$ (1996). Naloxone partial reversal of the antinociception produced by dipyrone microinjected into periaqueductal gray of rats. Possible involvement of medullary offand on-cells. Brain Research, 725: 106-110.

13. de Souza FR, Fighera MR, Lima TTF, Bastiani J, Barcellos IB, Almeida CE, Oliveira MR de, Bonacorso HG, Flores AE \& Mello CF de (2001). 3-Methyl-5-hydroxy-5-trichlomethyl-1 H-1-pyrazolcarboxyamide induces antinociception. Pharmacology, Biochemistry, and Behavior, 68: 525-530.

14. Zimmermann M (1983). Ethical guidelines for investigations of experimental pain in conscious animals. Pain, 16: 109-110.

15. Martins MAP, Sinhorin AP, Zimmermann NEK, Zanatta N, Bonacorso HG \& Bastos GP (2001). A convenient synthesis of 5-trichloromethyl-5-hydroxy-3-heteroalkyl-4,5-dihydroisoxazoles. Synthesis, 13: 1959-1964.

16. Martins MAP, Sinhorin AP, Rosa A et al. (2002). Regiospecific allylic mono- and dibromination of 4-methoxy-1,1,1-trihalo-3-alken-2-ones and 5-methoxy-1,1,1,2,2-pentafluoro-4-hexen-2-one, and their applications to the synthesis of heterocycles. Synthesis, 16: 2353-2358.

17. Siegfried B, Netto CA \& Izquierdo I (1987). Exposure to novelty induces naltrexone-reversible analgesia in rats. Behavioral Neuroscience, 101: 436-438.

18. Janssen PAJ, Niemegeers CJE \& Dony JGH (1963). The inhibitory effect of fentanyl and other morphine-like analgesics on the warm water induced tail withdrawal reflex in rats. Arzneimittel-Forschung (Drug Research), 15: 502-507.

19. Tsuda M, Suzuki T, Misawa M \& Nagase H (1996). Involvement of the opioid system in the anxiolytic effect of diazepam in mice. European Journal of Pharmacology, 307: 7-14.

20. Rubin MA, Albach CA, Berlese DB, Bonacorso HG, Bittencourt SRC, Queiroz CMT, Maixner AE \& Mello CF (2000). Anxiolytic-like effects of 4-phenyl-2-trichloromethyl-3H-1,5-benzodiazepine hydrogen sulfate in mice. Brazilian Journal of Medical and Biological Research, 33: 1069-1073.

21. Tabarelli Z, Berlese DB, Sauzem PD, Mello CF \& Rubin MA (2003). Antinociceptive effects of Cremophor EL orally administered to mice. Brazilian Journal of Medical and Biological Research, 36: 119123.

22. Akman H, Aksu F, Gultekin I, Ozbeck H, Oral U, Doran F \& Baysal F (1996). A possible central antinociceptive effect of dipyrone in mice. Pharmacology, 53: 71-78.

23. Ora I, Takahashi N, Funada M, Ujike H, Revay RS, Donovan DM, Miner LL \& Uhl GR (1997). Opiate receptor knockout mice define mu receptor roles in endogenous nociceptive responses and morphine-induced analgesia. Proceedings of the National Academy of Sciences, USA, 94: 1544-1549.

24. Endoh T, Matsuura H, Tajima A et al. (1999). Potent antinociceptive effects of TRK-820, a novel kappa-opioid receptor agonist. Life Sciences, 65: 1685-1694.

25. Kovelowski CJ, Bian D, Hruby VJ, Lai J, Ossipov MH \& Porreca F (1999). Selective opioid delta agonists elicit antinociceptive supraspinal/spinal synergy in the rat. Brain Research, 843: 12-17.

26. Tseng LF, Narita M, Suganuma C, Mizoguchi H, Ohsawa M, Nagase $H$ \& Kampine JP (2000). Differential antinociceptive effects of endomorphin-1 and endomorphin-2 in the mouse. Journal of Pharmacology and Experimental Therapeutics, 292: 576-583.

27. Takeda H, Tsuji M \& Matsumiya $T$ (1998). Changes in head-dipping behavior in the hole-board test reflect the anxiogenic and/or anxiolytic state in mice. European Journal of Pharmacology, 350: 21-29.

28. Grevert P \& Goldstein A (1977). Some effects of naloxone on behavior in the mouse. Psychopharmacology, 53: 111-113.

29. Katz RJ \& Gelbart J (1978). Endogenous opiates and behavioral responses to environmental novelty. Behavioral and Neural Biology, 24: 338-348.

30. Katz RJ (1979). Naltrexone antagonism of exploration in the rat. International Journal of Neuroscience, 9: 49-51.

31. Rotta FT, Mello CF, Rocha JBT \& Souza DOG (1988). Early undernutrition blocks the effect of naltrexone on rat exploratory behavior. Brazilian Journal of Medical and Biological Research, 21: 305-312.

32. Rocha JBT \& Mello CF (1994). Handling during suckling alters rat behavior but does not reverse the deleterious effects of undernutri- 
tion on naltrexone-induced inhibition of exploratory activity. International Journal for Vitamin and Nutrition Research, 64: 152-156.

33. Marita M, Suzuki T, Funada M, Misawa M \& Nagase H (1993). Involvement of $\delta$-opioid receptors in the effects of morphine on locomotor activity and the mesolimbic dopaminergic system in mice. Psychopharmacology, 111: 423-426.

34. Marita M, Takahashi Y, Takamori K, Funada M, Suzuki S, Misawa M \& Nagase $H$ (1993). Effects of kappa-agonist on the antinociception and locomotor enhancing action induced by morphine in mice. Japanese Journal of Pharmacology, 62: 15-24.

35. Mansour A, Fox CA, Akil H \& Watson SJ (1995). Opioid-receptor mRNA expression in the rat CNS: anatomical and functional implications. Trends in Neurosciences, 18: 22-29.

36. Spanagel R (1995). Modulation of drug-induced sensitization pro- cesses by endogenous opioid systems. Behavioural Brain Research, 70: 37-49.

37. Matsumoto RR, Brinsfield KH, Patrick RL \& Walker JM (1988). Rotational behavior mediated by dopaminergic and nondopaminergic mechanisms after intranigral microinjection of specific mu, delta and kappa opioid agonists. Journal of Pharmacology and Experimental Therapeutics, 246: 196-203.

38. Pan ZZ (1998). mu-Opposing actions of the kappa-opioid receptor Trends in Pharmacological Sciences, 19: 94-98.

39. Kuzmin A, Sandin J, Terenius L \& Ögren S (2000). Dose- and timedependent bimodal effects of $\kappa$-opioid agonists on locomotor activity in mice. Journal of Pharmacology and Experimental Therapeutics, 295: 1031-1042. 